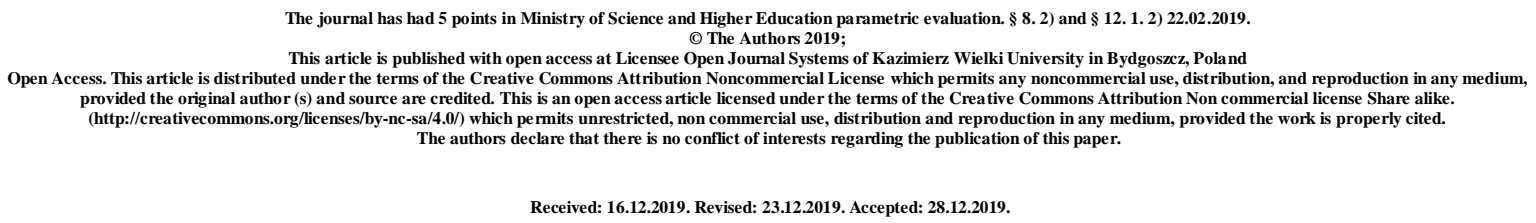

\title{
TREATMENT EFFECTIVENESS OF NEONATAL SEPSIS FORMED IN THE CONDITIONS OF ADVERSE ECOLOGICAL ENVIRONMENT
}

\author{
Olena Vasylivna Vlasova- Candidate of Medical Sciences, Doctoral Student of the \\ Department of Pediatrics and Children's Infectious Diseases of HSEE of Ukraine \\ "Bukovinian State Medical University", Chernivtsi, Ukraine, \\ e-mail: vlasovaolena01 @gmail.com https://orcid.org/000-0003-4253-0731
}

Mariana Ivanivna Hrytsiuk- Doctor of Medical Sciences, Head of the Department of Social Medicine and Public Health of HSEE of Ukraine "Bukovinian State Medical University", Chernivtsi, Ukraine;

e-mail: m.grytsiuk@gmail.com; http://orcid.org/0000-0003-1000-6417

\section{Abstract}

The analysis of the effectiveness of treatment of patients in the newborn comparison groups allowed to confirm that, taking into account the relative risk reduction of its manifestations, in the children of the main group, it was less successful in the first clinical group, although the mortality due to sepsis in these patients was not significantly higher $(7,8$ $\pm 2.2 \%$ in group I and $6.7 \pm 2.2 \%$ in group II, $\mathrm{P}>0.05$ )

Key words. neonatal sepsis; environmental factors; treatment effectiveness.

\section{Introduction.}

A review of the scientific literature on neonatal sepsis suggests that it is an urgent medical and social problem that has not yet been resolved. In addition, it is noted that adverse environmental factors of the environment, even at low intensity of influence on the parents, disturb the normal development of the fetus, causing structural, exchange and epigenetic 
abnormalities. On this basis, the working hypothesis of this study was the assumption that these abnormalities of intrauterine development may influence the features of neonatal sepsis and its treatment. We have not found any such studies when reviewing the scientific literature. Therefore, the purpose of the work was to analyze the effectiveness of treatment of children with neonatal sepsis, which was formed in the face of environmental problems.

\section{Material and methods}

The study involved 260 infants who had neonatal sepsis in 2015 -2018. The examination of patients was carried out in the neonatal wards of the CME "Regional Children's Hospital" in Chernivtsi, as well as in the relevant wards of the Khmelnytskyi City Children's Hospital and the Khmelnytskyi Regional Perinatal Center (within the Khmelnytskyi Regional Children's Hospital). These were the inclusion criteria: parents' informed consent to the study; presence of diagnostic criteria for sepsis in the child; neonatal period of life; permanent residence of parents in places with a certain amount of environmental burden of environmental factors on the organism. These were the noninclusion criteria: birth defects in the newborns; suspicion or presence of a primary immunodeficiency state and congenital errors of metabolism in the child; significant changes in the principles of sepsis treatment in newborns; some tactical points that did not allow a comprehensive examination of newborns.

Diagnosis and treatment of neonatal sepsis was performed according to the recommendations of leading neonatologists of Ukraine [1, 2, 3], taking into account international recommendations $[4,5]$. The proposed environmental risk factor (ERF), taking into account the environmental situation in the regional centers, was a criteria for group formation to assess the long-term load of anthropogenic air, water and soil pollution on the organism of newborns' parents in the regions. For instance, the first clinical group (the main one) included patients with neonatal sepsis, whose parents were permanent residents in places with ERF 2.0 or more and with unfavorable environmental characteristics of the regional center. This clinical group will hereinafter be referred to as the "main one" or "high environmental risk" (HER) group. The second group (the comparative one) was formed by newborns with sepsis, whose parents resided permanently in territories with low risk of adverse influence of these environmental factors on their body (ERF <2.0). This clinical group will be referred to as the "Comparison Group" or the "Low Environmental Risk" Group (LER).

General clinical description of patients in the comparison groups is shown in tables 1 
Table 1 - General clinical description of patients

\begin{tabular}{|l|c|c|c|}
\hline \multirow{2}{*}{$\begin{array}{l}\text { Clinical } \\
\text { Groups }\end{array}$} & \multirow{2}{*}{$\begin{array}{c}\text { Number of } \\
\text { patients }\end{array}$} & \multicolumn{2}{|c|}{$\begin{array}{c}\text { Incidence abs, }(\%) \\
\text { Place of parents' residence }\end{array}$} \\
\cline { 3 - 4 } & & Region centre & District centre \\
\hline I (main) & 141 & $48(34 \%)$ & $93(66 \%)$ \\
\hline II (comparative) & 119 & $31(26 \%)$ & $88(74 \%)$ \\
\hline P & $>0,05$ & $>0,05$ \\
\hline
\end{tabular}

It suggests that the data of the comparison group were not significantly different on the main clinical characteristics.

The study was conducted using the "experiment - control" method in parallel groups using a simple random sample. The design of a non-randomized controlled examination envisaged the identification of clinical, laboratory and instrumental features in children with neonatal sepsis whose parents resided permanently in places of different ecological and hygienic characteristics. The design of the study also envisaged, on the basis of a comprehensive examination of patients with neonatal sepsis, depending on the ecological characteristics of their parents' places of residence, studying the risk indicators of the disease and its treatment with the creation of an algorithm for personalized management of patients.

Comprehensive examination of patients with neonatal sepsis was performed on the first day of the disease, that is, the day of diagnosis, as well as on the 3rd and 7th day of treatment.

The environmental situation in the place of residence of the parents was evaluated in accordance with the methodological recommendations [6, 7]. Complex anthropo-technogenic load on the environment, taking into account the bioavailability of soil, water and air pollutants in some areas of the region, by the magnitude of the proposed environmental risk factor $(E R F)$, which was determined by the formula:

A comprehensive examination of the infants was performed in the neonatal wards after the diagnosis of sepsis on the 1st, 3rd and 7th day of the disease.

The results of the study were analyzed using the Statistica 6 software package Stat Soft and Excell XP for Windows on a personal computer using parametric and nonparametric calculation methods. The diagnostic value of the tests was determined taking into account their sensitivity, specificity, predicted value of positive and negative results, determining their $95 \%$ confidence intervals $(95 \% \mathrm{CI})$. The risk of the event was assessed based on attributive (AR) and relative (RR) risks, taking into account the odds ratio (OR). The efficacy of treating sepsis in newborns was assessed by reducing the absolute (RAR) and 
relative (RRR) risks, taking into account the minimum number of patients who should be treated to obtain one positive result (MNP).

\section{Discussion}

Treatment of neonatal sepsis was performed in accordance with the recommendations of leading neonatologists of Ukraine [1, 2] and taking into account international consentaneous documents $[4,5]$. Thus, $79.8 \%$ of children in the first clinical group and $71.4 \%$ of patients in the comparison group needed oxygen supplementation at the start of sepsis treatment. In $65.3 \%$ of cases, newborns of the main group were subjected to ventilator support (IVL) while among patients of group II such need for ventilation arose in $46.3 \%$ of cases.

The need for prescribing vasoactive amines (dopamine, dobutamine, adrenaline) at the 1st day of sepsis treatment appeared in the first clinical group in $31.4 \%$ of cases, and among patients in the comparison group - in $18.5 \%$ of observations. Below are the data for reducing the risk of an event relative to the first day of treatment. Table 2 shows the indicators for reducing the risk of oxygen supplementation and the use of vasoactive amines.

Table 2 - Reducing the examination risk of vasoactive amines and oxygen supplementation of children in comparison groups.

\begin{tabular}{|c|c|c|c|c|c|c|c|c|}
\hline \multirow{2}{*}{ Indicators } & \multicolumn{3}{|l|}{ Relative risk reduction, \% } & \multicolumn{4}{c|}{ NPNT* } \\
\cline { 2 - 10 } & $\begin{array}{l}\text { 3rd day of } \\
\text { treatment }\end{array}$ & $\begin{array}{l}\text { 7th day of } \\
\text { treatment }\end{array}$ & \multicolumn{2}{c|}{$\begin{array}{l}\text { 3rd day of } \\
\text { treatment }\end{array}$} & \multicolumn{2}{|c|}{$\begin{array}{c}\text { 7th day of } \\
\text { treatment }\end{array}$} \\
\cline { 2 - 10 } & $\begin{array}{c}\text { I } \\
\text { group }\end{array}$ & $\begin{array}{c}\text { II } \\
\text { group }\end{array}$ & $\begin{array}{c}\text { I } \\
\text { group }\end{array}$ & $\begin{array}{c}\text { II } \\
\text { group }\end{array}$ & $\begin{array}{c}\text { I } \\
\text { group }\end{array}$ & $\begin{array}{c}\text { II } \\
\text { group }\end{array}$ & $\begin{array}{c}\text { I } \\
\text { group }\end{array}$ & $\begin{array}{c}\text { II } \\
\text { group }\end{array}$ \\
\hline $\begin{array}{c}\text { Oxygen } \\
\text { supplementation }\end{array}$ & 12,3 & 15,8 & 28,6 & 37,4 & 10,2 & 8,8 & 4,3 & 3,7 \\
\hline $\begin{array}{c}\text { Ventilator } \\
\text { support (IVL) }\end{array}$ & 4,0 & 18,3 & 33,8 & 35,6 & 38,5 & 11,7 & 4,4 & 6,0 \\
\hline $\begin{array}{c}\text { Vasoactive } \\
\text { amines }\end{array}$ & 28,7 & 40,6 & 28,6 & 11,9 & 11,0 & 14,2 & 22,2 & 45,4 \\
\hline
\end{tabular}

Note.* - number of patients who need to be treated for a positive result.

These data suggest that the effectiveness of sepsis treatment in newborns whose parents lived in high-risk areas was less successful than in the comparison group.

Figure 1 shows the indicators of the relative risk reduction for the central type cyanosis and clinical signs of respiratory distress in the form of involvement of compliant areas of the chest with inflating of the nose alae in children of comparison groups on the 3rd and 7 th days of treatment of sepsis. 


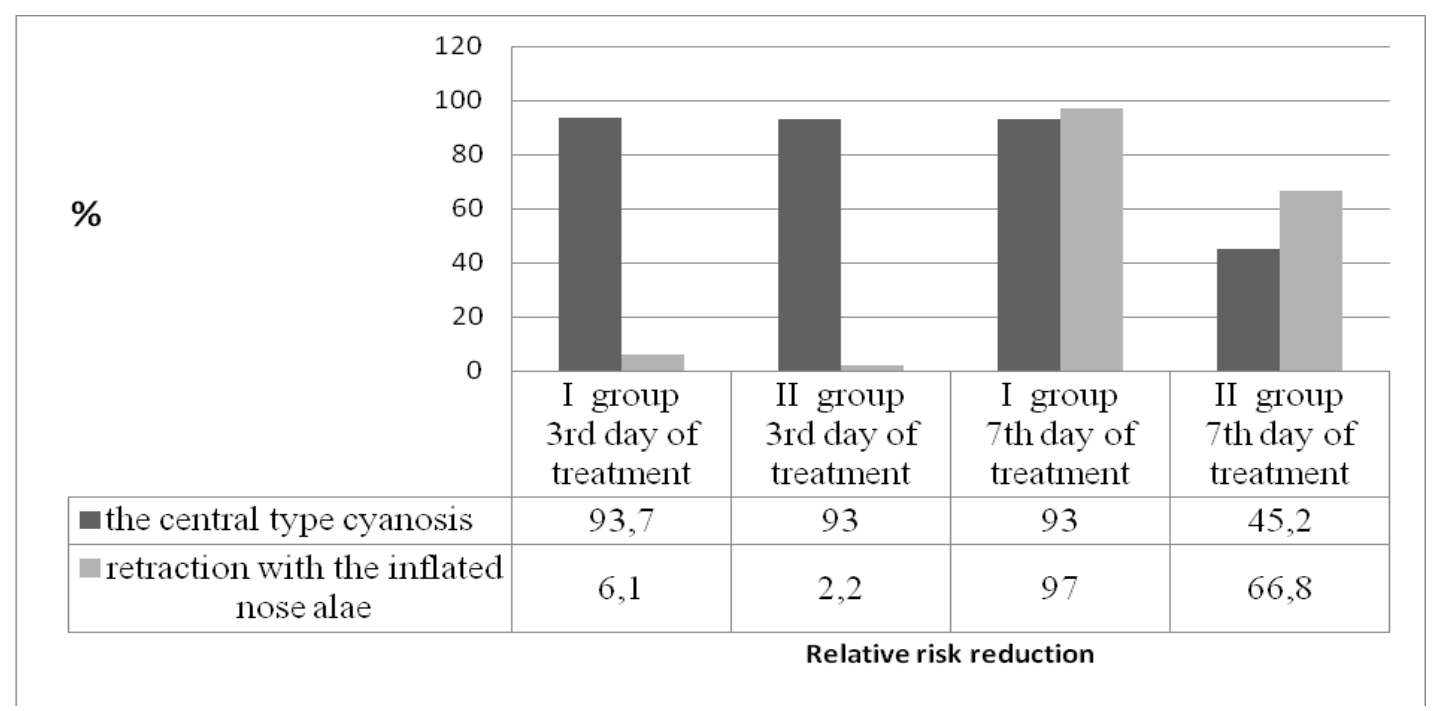

Fig.1 Relative risk reduction for the central type cyanosis and signs of respiratory distress in children of comparison groups at the 3rd and 7th day of treatment.

Thus, the relative risk of a decrease in central-type cyanosis cases at the $3 \mathrm{rd}$ and 7 th day of treatment was not significantly different in the comparison groups, apparently due to the oxygen supplementation given to these children. At the same time, even at the 7 th day of sepsis treatment of newborn group I, the reduction in the relative risk of respiratory distress was significantly lower than in the comparison group.

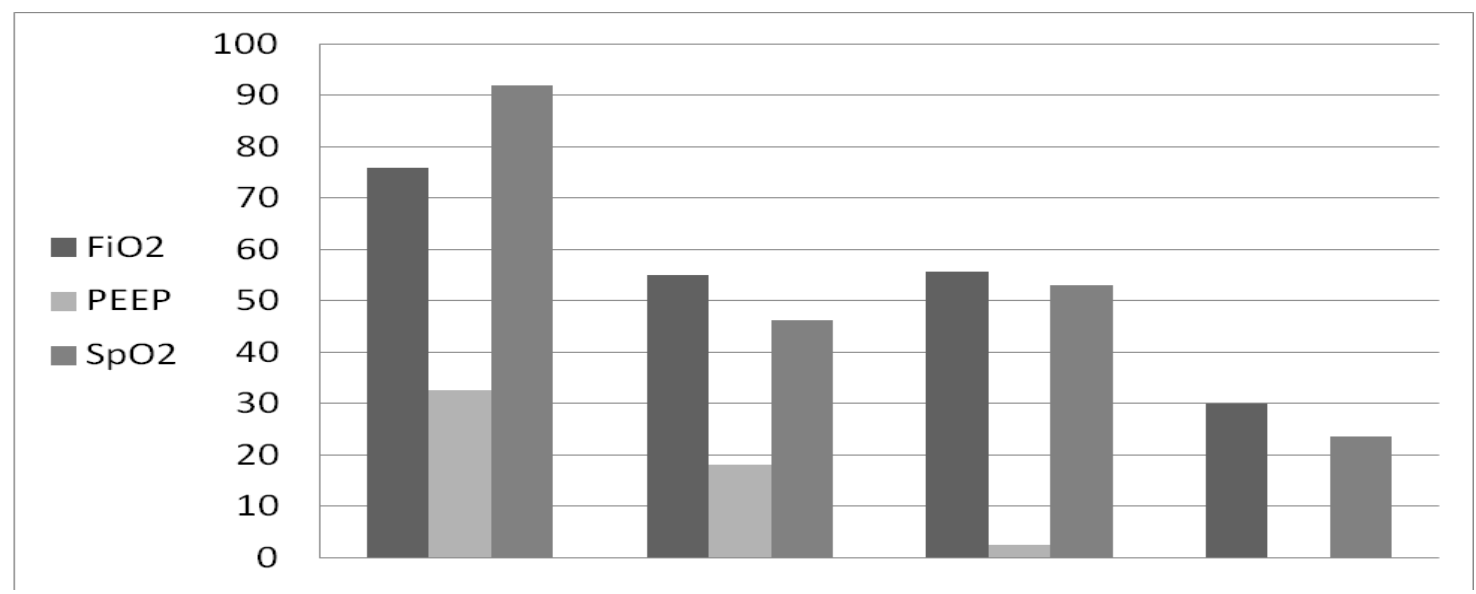

\begin{tabular}{|l|c|c|c|c|}
\hline \multirow{2}{*}{ Indicators } & \multicolumn{4}{|c|}{ Relative risk reduction } \\
\cline { 2 - 5 } & \multicolumn{3}{|c|}{ 3rd day of treatment } & \multicolumn{2}{|c|}{ 7th day of treatment } \\
\cline { 2 - 5 } & I group & II group & I group & II group \\
\hline FiO2 $\geq 0,5$ & 75,8 & 55,1 & 55,7 & 29,9 \\
\hline PEEP $\geq 5 \mathrm{~cm} . \mathrm{wg}$ & 32,5 & 18,2 & 2,6 & - \\
\hline $\mathrm{SpO} 2<90 \%$ & 91,9 & 46,3 & 53,1 & 23,7 \\
\hline
\end{tabular}

Fig. 2 Reducing the relative risk of aggressive ventilation methods in children of comparison groups. 
Patients with respiratory disorders sepsis required an oxygen supplementation using a gas mixture containing $50 \%$ or more oxygen content at a positive exhalation pressure of more than $5.0 \mathrm{~cm}$. wg. Figure 2 shows the relative risk reduction for such treatment at the $3 \mathrm{rd}$ day and the 7th day of intensive sepsis.

These data suggest that the aggressive ventilation regimen was more effective on day 3 of treatment in group I of the patients, but on day 7, the reduction in relative risk was less pronounced than on day 3 of therapy, which, apparently, evidence of acute lung injury in previous days of life.

Table 3 - Lists the risk reduction indicators for markers that reflect cardiovascular disorders during treatment.

\begin{tabular}{|c|c|c|c|c|c|c|c|c|}
\hline \multirow{2}{*}{ Indicators } & \multicolumn{4}{|c|}{ Relative risk reduction, \% } & \multicolumn{4}{c|}{ NPNT* } \\
\cline { 2 - 9 } & \multicolumn{2}{|c|}{$\begin{array}{c}\text { 3rd day of } \\
\text { treatment }\end{array}$} & \multicolumn{2}{c|}{$\begin{array}{c}\text { 7th day of } \\
\text { treatment }\end{array}$} & \multicolumn{2}{c|}{$\begin{array}{c}\text { 3rd day of } \\
\text { treatment }\end{array}$} & \multicolumn{2}{c|}{$\begin{array}{c}\text { 7th day of } \\
\text { treatment }\end{array}$} \\
\cline { 2 - 9 } & $\begin{array}{c}\text { I } \\
\text { group }\end{array}$ & $\begin{array}{c}\text { II } \\
\text { group }\end{array}$ & I group & $\begin{array}{c}\text { II } \\
\text { group }\end{array}$ & $\begin{array}{c}\text { I } \\
\text { group }\end{array}$ & $\begin{array}{c}\text { II } \\
\text { group }\end{array}$ & $\begin{array}{c}\text { I } \\
\text { group }\end{array}$ & $\begin{array}{c}\text { II } \\
\text { group }\end{array}$ \\
\hline Tachycardia & 64,0 & 68,3 & 74,5 & 62,7 & 7,8 & 9,0 & 6,7 & 10 \\
\hline Bradycardia & 27,3 & - & 63,6 & 80,0 & 30,3 & - & 9,2 & 14,7 \\
\hline $\begin{array}{c}\text { Heart tones } \\
\text { muting }\end{array}$ & 6,9 & 7,0 & 18,5 & 23,3 & 18,5 & 23 & 7,0 & 7,0 \\
\hline $\begin{array}{l}\text { «hite Spot» } \\
>3 \text { ceк. }\end{array}$ & 48,1 & 52,7 & 1,5 & 59,6 & 7,8 & 13 & 25 & 12,6 \\
\hline
\end{tabular}

As it can be seen from the above data, the relative risk of decreased severity of symptoms such as bradycardia, heart tones muting, capillary bed filling rate was more pronounced in the patients of the comparison group, which led to the conclusion that there is more successful treatment of these patients than the newborns of the main group. Taking into account the disturbance of the functional state of the cardiovascular system, it seemed appropriate to determine the reduction of the relative risk of arterial hypotension in the examined children on the 7th day of treatment (Fig.3).

As it can be seen from the presented data, the newborns of the main group on the 7th day of treatment of sepsis had a more pronounced response to the treatment than patients of the comparison group. Moreover, cases of decrease in diastolic blood pressure up to $30.0 \mathrm{~mm}$ $\mathrm{Hg}$ or less occurred in these children at day 1 of the disease in $46.3 \%$ of cases, and at day 7 of treatment - in $48.2 \%$ of observations. Perhaps a more pronounced reduction in the risk of arterial hypotension in patients in the main group was associated with more frequent use of such drugs as dopamine and dobutamine. Thus, these cardio- and vasoactive amines were 
administered at day 1 of treatment in patients of the main group in $31.4 \%$ of cases, and in the newborn of the comparison group - in $18.5 \%$ of observations $\mathrm{P}<0.05)$. The reduction of the relative risk of the need to prescribe these drugs for the 3rd day of treatment in the first group of patients was $28.7 \%$, and in newborns of the second group - 3.7\%. At day 7 , treatment for reducing this risk was $14.3 \%$ in group I and $11.9 \%$ in comparison group, respectively. On average, these adrenergic drugs were used in children of the main group for $6.3 \pm 0.7$ days, and for infants in the comparison group, for $5.4 \pm 0.7$ days $(\mathrm{P}>0.05)$.

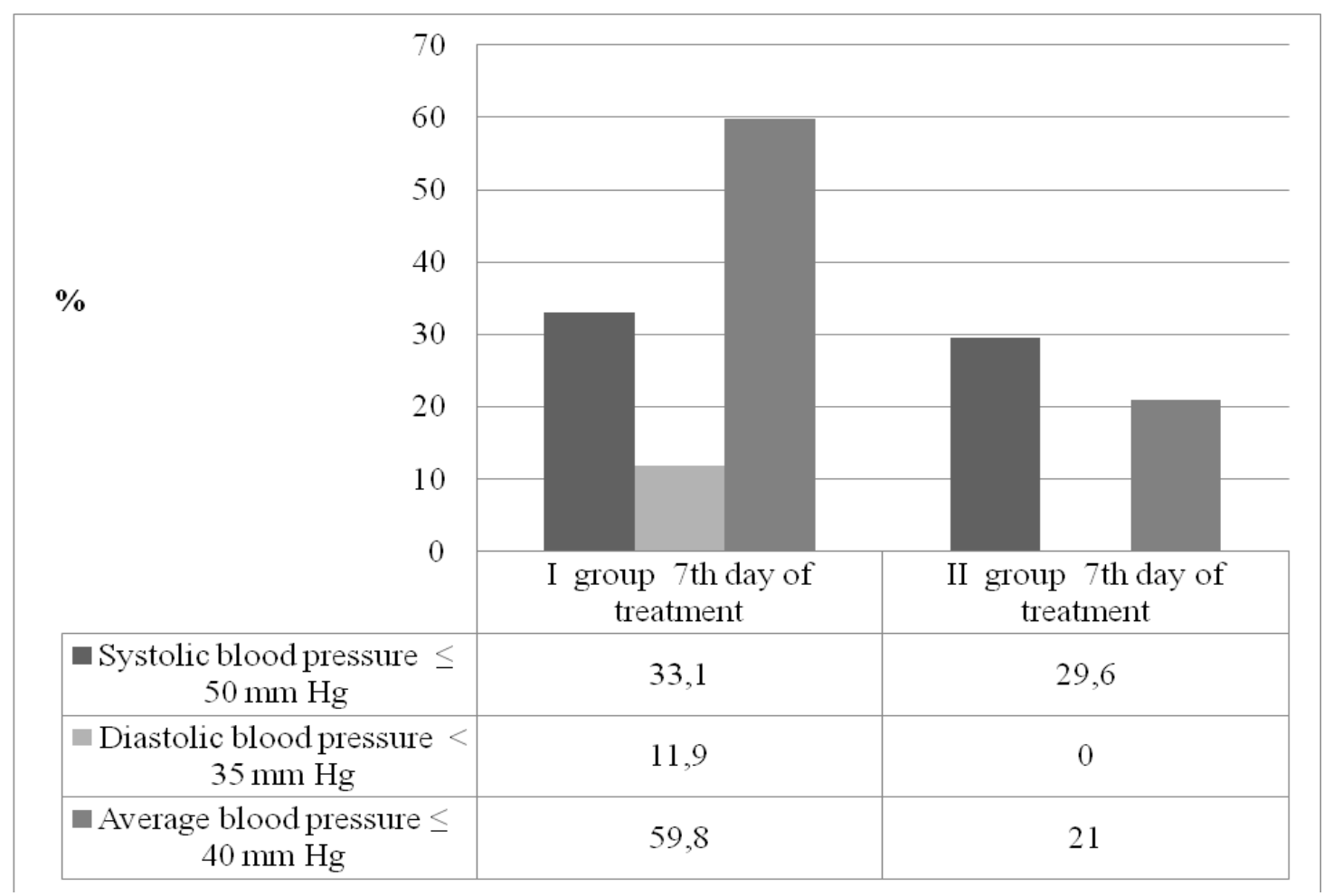

Fig.3 Reduction of relative risk of arterial hypotension on the 7th day of treatment of sepsis.

It should be noted that the decrease in the relative risk of symptoms of neurological disorders such as hyporeflexia, excitation of the child, the presence of a shrill cry for the first 3 days of treatment was insignificant and coincided in both comparison groups.

The frequency of convulsive syndrome increased on the 3rd day of treatment in both the children of the main group and the patients of the comparison group. Thus, in the main group, generalized seizures of clonic-tonic nature were observed on the 1st day of the disease in $8.5 \%$ of cases, and on the 3rd day of treatment - in $10.8 \%$ of observations. Apparently, this was in some cases due to hyponatremia (less than $130.0 \mathrm{mmol} / \mathrm{l}$ ), which on the 1st day of the disease occurred in these patients in $7.0 \%$ of cases, and on the 3rd day of treatment - in $14.6 \%$ 
of observations. In addition, an increase in the frequency of convulsive syndrome may be associated with hypoglycemia. Thus, a decrease in blood glucose content of less than 3.0 mmol / 1 was observed in the first clinical group in $27.3 \%$ of cases, and in the newborn comparison group - in $12.5 \%$ of observations. The decrease in the relative risk of this hypoglycemia on the 3rd day of treatment of sepsis was $34.2 \%$ in the newborns of the main group, and $61.3 \%$ in the patients of the comparison group.

Reduction of relative risk of disturbance of the state of consciousness, assessed by the modified Glasgow scale, with constellation less than 7 points, on the 3rd day of sepsis treatment in newborns of the main group was $25,0 \%$, and in patients of the comparison group $-20,3 \%$ of observations $(\mathrm{P}>0.05)$.

In Fig. 4 Indicators of relative risk reduction of such symptoms of a functional state disturbance of a gastrointestinal tract as lack of tolerance to food and a sucking reflex, and also need for parenteral nutrition are given.

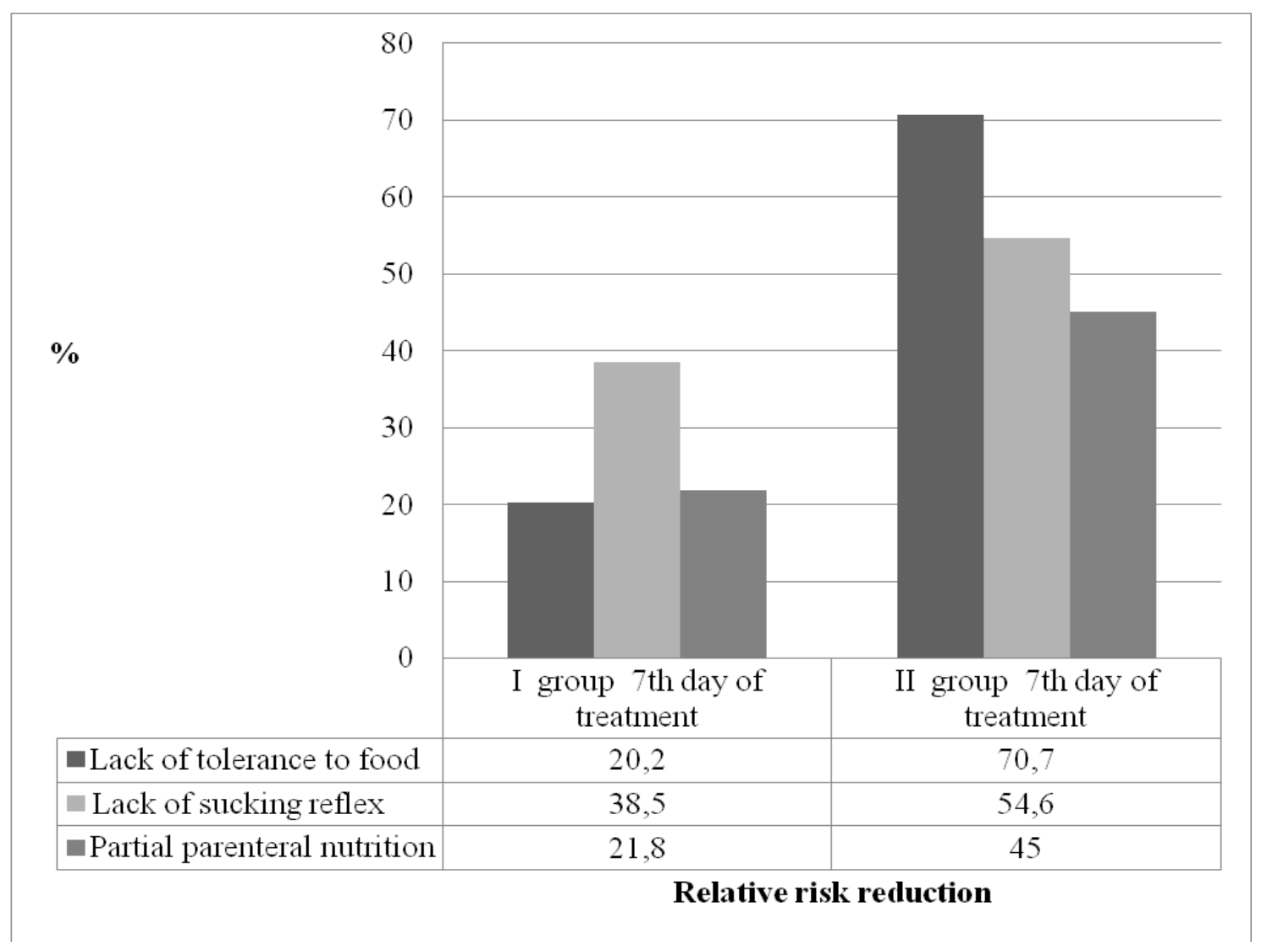

Fig. 4 Reducing the relative risk of disorders such as lack of food tolerance, sucking reflex and the need for parenteral nutrition on the 7th day of treatment for sepsis.

These data give grounds to conclude that during the treatment of sepsis in patients of the comparison group II, the disorders of the digestive system's functional state were 
presented and the need for partial parenteral nutrition was significantly more frequent than in the newborns of the main group. The need for full parenteral nutrition in the first clinical group occurred in $14.0 \%$ of cases, and in the comparison group - in $13.2 \%$ of observations. On the 7 th day of treatment, the situation remained the same.

Impaired renal excretory function in patients with sepsis was manifested as a decrease in urinary excretion and an increase in serum creatinine content. Thus, a decrease in diuresis of less than $1.0 \mathrm{ml} / \mathrm{kg} / \mathrm{h}$ on day 1 of sepsis treatment occurred in every fourth child of the first group and in every sixth newborn comparison group. The serum creatinine content of more than $100.0 \mu \mathrm{mol} / 1$ was found in $26.8 \%$ of the patients in the main group and $10.3 \%$ of the newborns in the comparison group.

Figure 5 shows the relative risk reduction of diuresis less than $1.0 \mathrm{ml} / \mathrm{kg} / \mathrm{h}$ in children of the comparison groups on day 3 and day 7 of sepsis treatment.

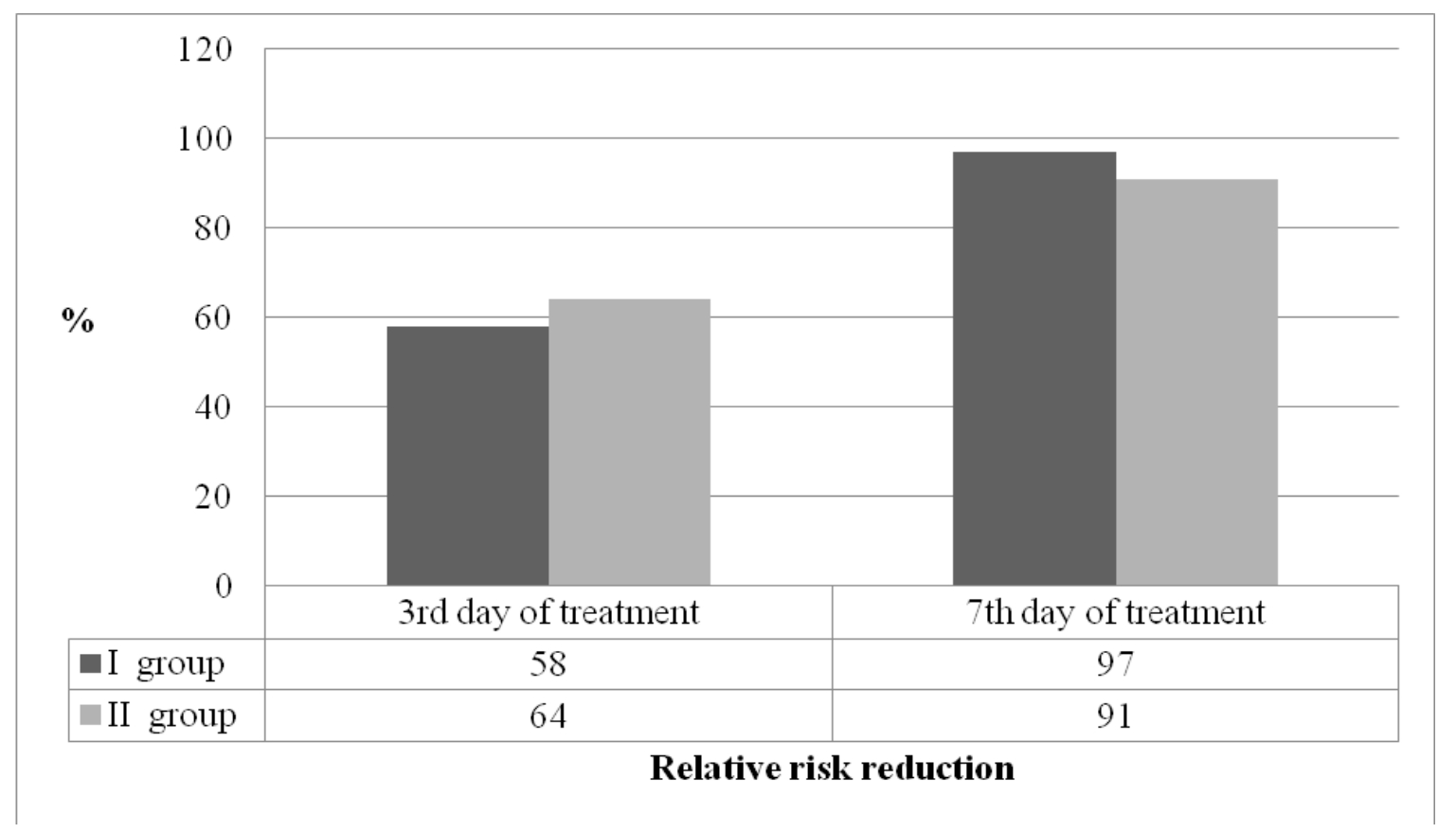

Fig.5 Decrease in relative risk of diuresis less than $1.0 \mathrm{ml} / \mathrm{kg} / \mathrm{h}$ in children of comparison groups on the $3 \mathrm{rd}$ and 7 th day of treatment of sepsis.

As follows from the data presented, the reduction in the relative risk of the daily diuresis in the clinical groups was not significantly different. On the 3rd day of treatment for sepsis, normal diuresis recovered in almost all patients. Despite this, the risk ratio of serum creatinine content greater than $100.0 \mu \mathrm{mol} / 1$ in the newborns of the main group was 2.0 on the 1st day of treatment (95\% CI 0.8-3.12), on day 3 - 1,5 (95\% CI 0,94-2,38) and on the 7th day - 1,23 (95\% CI 0,87-1,72). 
It should be noted that by the 7th day of treatment for sepsis, the content of electrolytes such as sodium and potassium in the serum of representatives was predominantly adjusted. Thus, if in the neonates of the main group the ratio of the chances of hypo- or hypernatremia was 4.7 (1.04) (95\% CI 0.35-3.15) on the 1 st day of treatment for sepsis, then on the 7th day - $1,3(0.36)$ (95\% CI 0.1-1.25). The ratio of the chances of hypokalemia less than $3.5 \mathrm{mmol} / 1$ in the serum of these patients on the 1st day of treatment was $7.9(95 \% \mathrm{CI}$ 2,33-27,1), and on the 7th day - 1,3 (95\% CI 0.52-3.18). Decreases in serum calcium levels of newborns in the main group during the first week of sepsis treatment occurred more frequently than in the comparison group children. Thus, in patients of group I, cases of hypocalcemia (less than $1.2 \mathrm{mmol} / \mathrm{l}$ ) on the 1st day of treatment of sepsis amounted to $28.8 \%$, and in newborns of group II the indicated calcium content was noted in patients $35.7 \%$. On day 7 of sepsis treatment, these markers were $80.0 \%$ and $50.0 \%$, respectively. The risk ratio of hypocalcemia in the first clinical group on day 1 of treatment of sepsis was 0.85 (95\% CI 0.6-1.3), and on day 7 - 0.64 (2.15) (95\% CI 1,7-2,7).

Figure 6 shows the indicators for reducing the relative risk of hematologic changes according to the general blood test on the 7th day of treatment for sepsis.

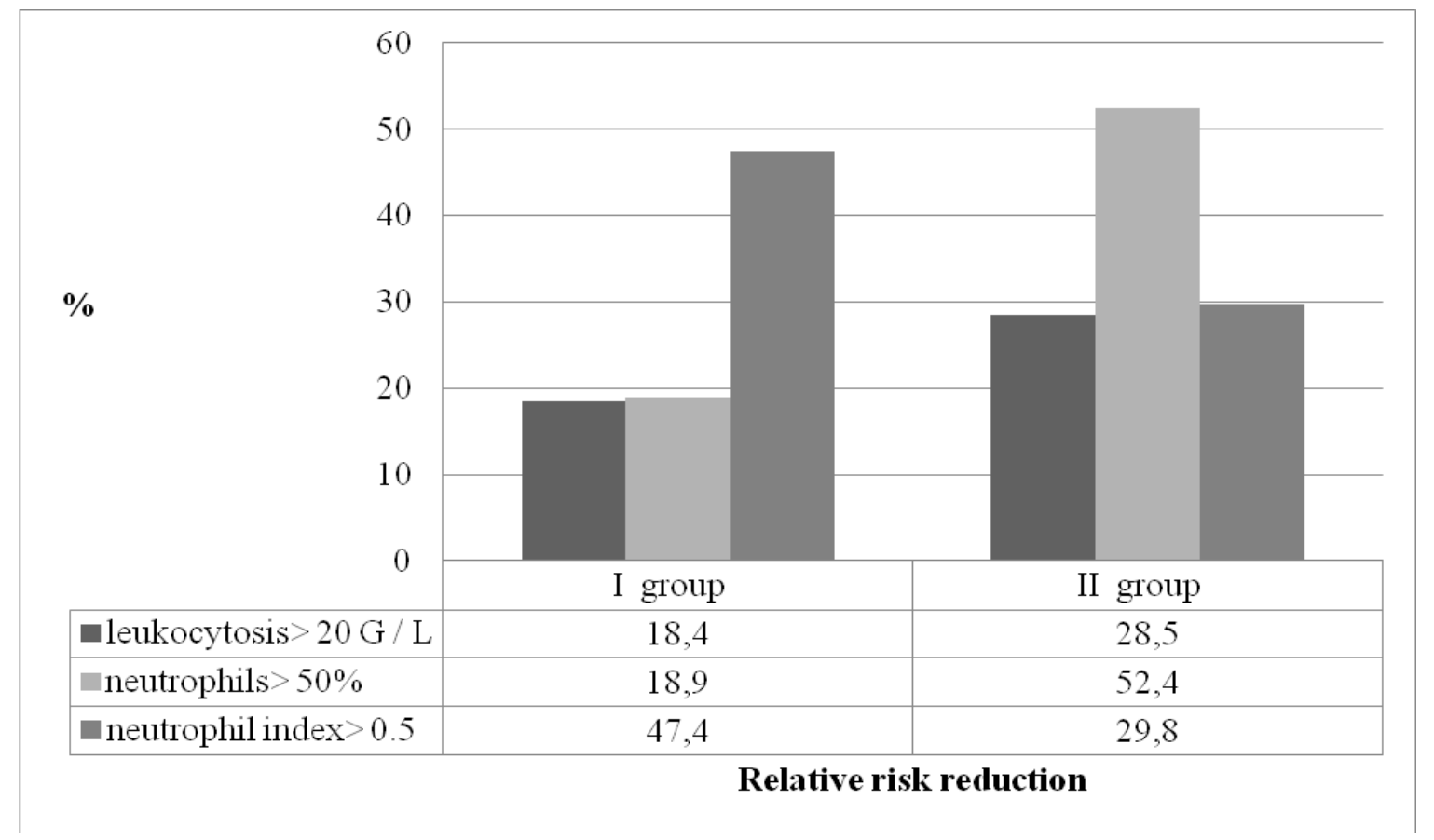

Figure 6 Reduction of the relative risk of inflammation according to the data of the general blood test on the 7 th day of treatment of sepsis.

As it follows from the data in Fig. 5.6., the decrease in the relative risk on the 7th day of treatment of such indicators as leukocytosis, the relative content of neutrophilic 
granulocytes, was more pronounced in patients of group II. At the same time, the decrease in the neutrophil index, that is, the ratio of immature forms of neutrophil granulocytes to their total number, was more pronounced in the newborn-based group.

It should be noted that the ratio of the chances of neutrophil blood index of 0.5 and higher in children of group I on day 1 of the disease was 0.82 (1.0) (95\% CI 0.55-1.83), and 7- and sepsis treatment day was 1.32 (0.82) (95\% CI 0.46-1.47).

Table 4 - The nature of antibiotic therapy for neonatal sepsis.

\begin{tabular}{|c|c|c|c|c|c|c|}
\hline \multirow{2}{*}{$\begin{array}{c}\text { Clinical } \\
\text { groups }\end{array}$} & \multicolumn{5}{|c|}{ Courses of antibiotic therapy of neonatal sepsis } \\
\cline { 2 - 7 } & \multicolumn{2}{|c|}{ First } & \multicolumn{2}{c|}{ Second } & \multicolumn{2}{c|}{ Third } \\
\cline { 2 - 7 } & $\begin{array}{c}\text { Combination } \\
\text { a / b therapy }\end{array}$ & $\begin{array}{l}\text { Duration, } \\
\text { days }\end{array}$ & $\begin{array}{c}\text { Combination } \\
\text { a / b therapy }\end{array}$ & $\begin{array}{c}\text { Duration, } \\
\text { days }\end{array}$ & $\begin{array}{c}\text { Combina } \\
\text { tion a / b } \\
\text { therapy }\end{array}$ & $\begin{array}{c}\text { Duration, } \\
\text { days }\end{array}$ \\
\hline I group & $*$ & $5,4 \pm 0,52$ & $* *$ & $12,0 \pm 0,69$ & $* * *$ \\
& $81,7 \%$ & & $80 \%$ & & $78,3 \%$ & $13,8 \pm 0,79$ \\
& $* *$ & & $* * *$ & & $* *$ & \\
& $16,1 \%$ & & $20 \%$ & & $21,7 \%$ & \\
\hline II group & $*$ & $4,3 \pm 0,44$ & $* *$ & $7,9 \pm 0,65$ & $* * *$ & $12,2 \pm 1,01$ \\
& $94,9 \%$ & & $84,6 \%$ & & $84,6 \%$ & \\
& $* *$ & & $* * *$ & & $* *$ & \\
& $5,1 \%$ & & $15,4 \%$ & & $>0,4 \%$ & \\
\hline $\mathrm{p}$ & $>0,05$ & $>0,05$ & $>0,05$ & $<0,01$ & $>0,05$ & $>05$ \\
\hline
\end{tabular}

Note: $1 . *$ - A combination of penicillin + aminoglycosides

2. $* *$ - combination of cephalosporin + aminoglycosides

3. $* * *$ - combination of cephalosporin $+\mathrm{a} / \mathrm{b}$ reserve (vancomycin, meronome, colimycin)

The above data suggest that the tactics of treating neonatal sepsis in the comparison groups were not significantly different. Thus, the lower frequency of combination of the previous course of treatment became dominant in the future. In the following combinations, the generation of antibiotics usually changed to newer ones, and increasingly resorted to antibiotics reserve.

Infusion therapy at the beginning of sepsis was prescribed to all patients. For this purpose glucose-salt solutions were used, the composition, volume and rate of administration of which were determined on the basis of clinical and laboratory data. Thus, the duration of infusion therapy averaged 25.9 days in patients of the I group, and 18.0 days for the newborns in the comparison group $(\mathrm{P}<0.05)$. 
$64.7 \%$ of children in clinical group I and $27.3 \%$ of patients in the comparison group received intravenous immunoglobulin. The dose of saturation $(1.2 \mathrm{mg} / \mathrm{kg})$, evenly distributed, was administered over 3 days. A maintenance dose of immunoglobulin was not administered to our patients.

On average, the duration of inpatient treatment in the children of the main group was 44.1 bed-day and in the newborns of comparison group was $37.5(\mathrm{p}<0.01)$. Fatal cases were $7.8 \pm 2.3 \%$ and $6.7 \pm 2.3 \%$, respectively, in these patients $(p>0.05)$. And the ratio of the chances of such cases in group I was 1.24 (95\% CI 0.4-3.44).

\section{Conclusions}

Thus, these data suggest that the treatment of sepsis, given the reduction in the relative risk of its manifestations, in children of the main group was less effective than in the newborn comparison group. In addition, an analysis of the characteristics of sepsis in newborns, whose parents lived in high-risk areas, shows that it is characterized generally by a more severe course.

\section{References}

1. Znamenska T.K. Neonatolohyia: navchalnyi posibnyk. Kyiv: Assotsiatsiia neonatolohiv Ukrainy; 2012: 644-655 Ukrainian

2. Neonatolohiia: Natsionalnyi pidruchnyk: za red.. Ye.Ie. Shunko. Kyiv, 2015: 93138. Ukrainian

3. Nakaz MOZ №234 vid 10.05.2007r. «Pro orhanizatsiiu vnutrishno likarnianykh infektsii $\mathrm{v}$ akusherskykh statsionarakh». Ukrainian

4. Dellinger R.P. Surviving Sepsis Campaing: International Giidlelines for managements of severe sepsis and Septic Shock. Intensive Care Med.2013; 39: 165-228

5. Polin R.A. Management of Neonates with suspected or proven early-onset bacterial sepsis(Committee on fetus and newborn).Pediatrics.2012; 129(5): 1006-1013.

6. Metodicheskie rekomendatsii «Unifitsirovannyie metodyi sbora dannyih, annaliza i otsenki zabolevaemosti naseleniya $\mathrm{s}$ uchetom kompleksnogo deystviya faktorov okruzhayuschey sredyi» Moskva.1996.36. Russian

7. Metodicheskie rekomendatsii «Unifitsirovannyie metodyi sbora dannyih, annaliza i otsenki zabolevaemosti naseleniya $\mathrm{s}$ uchetom kompleksnogo deystviya faktorov okruzhayuschey sredyi» Moskva.1996. 38 Russian 